https://doi.org/10.18485/iipe_postsovjet.2021.ch2

Konstantin Lobanov ${ }^{1}$

Boris Selin

\title{
THE POST-SOVIET AREA: THE GEOPOLITICAL FIELD FOR RIVALRY BETWEEN THE WESTERN WORLD AND CHINA
}

\begin{abstract}
The contemporary architecture of international relations is rapidly changing towards a global bipolar structure of the world. It is obvious that the major centers of influence and power in this emerging framework will become the Western World headed by the United States and China. The authors of the article hypothesize the exceptional importance for these front-runners of involving the post-Soviet Eurasian republics and Russia in the orbit of their interests. The authors are endeavouring to confirm their assumptions by applying the categorical methodology of classical geopolitics. In particular, the post-Soviet sector of Eurasia has been considered as a dynamically transforming geopolitical field under the influence of the growing rivalry between the Western countries and China. Within the framework of the categorical system of the geopolitical field, the authors strove to assess objectively the opportunities for Russia's participation in managing these changes in its interests. The content of the article is based on current data, and the conclusions suggest that the authors are open to discussion on the topic.
\end{abstract}

Keywords: post-Soviet sector of Eurasia, geopolitical field, geopolitical rivalry, global geopolitical conflict, stratagem, Western World, the United States of America, China, Russia.

\footnotetext{
${ }^{1}$ Konstantin Lobanov, Professor, Belgorod State University, Russia, Belgorod, e-mail: lobanov.politika@gmail.com

Boris Selin, Associate Professor, Putilin Belgorod Law Institute of the Ministry of the Interior of the Russian Federation, Russia, Belgorod, e-mail: selin.boris@yandex.ru
} 


\section{The categorical framework of the geopolitical field within the context of global rivalry between the Western World and China}

In classical geopolitics, the geopolitical field is usually considered a space controlled by a state or a union of states. ${ }^{2}$ Being initially a non-static spatial environment for the subjects of world politics, the geopolitical field is constantly changed under the influence of global, regional and even local social processes and phenomena.

Russian researcher K.V. Pleshakov (Константин Викторович Плешаков) has identified several transformations of the geopolitical field. ${ }^{3}$ The initial point for subsequent internal changes is considered to be an endemic field, that is, a space controlled by the state for a long time. National control over the endemic field is generally not disputed by other states or their unions. A frontier field is a territorial area under the guidance of a certain state, but economically and politically insufficiently developed by it. Other contenders sometimes challenge the ability of the state to maintain control over the space, but they still do not consider these territories to be their own. The next type of geopolitical field is a cross field. Several actors may claim it. A meta-field is a space that is being developed de facto by several nations simultaneously. Finally, a total field is a constant space under the control of one nation or an alliance of nations. ${ }^{4}$ The variety of modifications of the geopolitical field is merely the result of its evolution, and therefore, this process is underpinned by a certain logic of development. Nationally organized subjects of world politics consider, as a rule, their own territory as an endemic field and strive to keep it as a total field. But international actors operating on a global scale aim to expand the total fields by means of cross, frontier and meta-fields absorption.

In particular, such a sequence of actions is inherent in the XXI century in the Western World headed by the United States of America (hereinafter referred to as the United States) and China, which were labeled by Henry Kissinger (Henry Alfred Kissinger) as "pillars of the world order". ${ }^{5}$ As the

\footnotetext{
${ }^{2}$ Наум М. Сирота, Геополитика, Питер, Санкт-Петербург, 2006, с. 12.

${ }^{3}$ Константин В. Плешаков, "Геополитика в свете глобальных перемен", Международная жизнь, 1994, №10, сс. 30-39.

${ }^{4}$ Константин В. Плешаков, "Геополитика в свете глобальных перемен", ор. cit., сc. 32-34.

${ }^{5}$ Henry Kissinger, World Order, Penguin, New York, 2014, p. 134.
} 
undisputed subjects of domination in the world economy in terms of such indicators as the proportion of the world's gross domestic product (hereinafter referred to as GDP), trade and export of capital ${ }^{6}$, as well as in terms of total military power ${ }^{7}$, the West and China are currently undergoing a process of consolidation as the only two global centers of influence and power. According to the British political scientist Arvind Subramanian (Arvind Subramanian), this process could be finalized by $2030 .{ }^{8}$ The internal integration of these centers of global leadership is accompanied by the determination of their peripheral zones around the world, the areas which already apparently include Southeast Asia, Latin America, sub-Saharan Africa and the expanded Middle East. ${ }^{9}$ Both the United States and China consider these macro-regions through the prism of their geo-economic and geopolitical interests as a set of extensive cross and meta-geopolitical fields that are subject to redevelopment in accordance with their own claims to global primacy. The clash of ambitions of world leaders inevitably leads to an intense rivalry that threatens to escalate into a conflict between them. Such lines of tension have already been drawn on the world map..$^{10}$ However, despite aggressive rhetoric and the intent to intimidate the

\footnotetext{
${ }^{6}$ Arvind Subramanian, Eclipse: Living in the Shadow of China's Economic Dominance, Peterson Institute for International Economics, Washington, 2011, p. 193.

7 "2020 Annual Report to Congress of the U.S.- China Economic and Security Review Commission (2020)", One Hundred Sixteenth Congress, Second Session, December 2020, Chapter 3 Section 1- Year in Review: Security, Politics, and Foreign Affairs, Washington, 2020, Internet: https://www.uscc.gov/2020 Annual Report to Congress /U.S.- China / Economic and Security Review Commission (uscc.gov), 18/02/2021, pp. 229-330.

${ }^{8}$ Arvind Subramanian, Eclipse: Living in the Shadow of China's Economic Dominance, op. cit., p. 194.

9 Роберт Д. Каплан, Месть географии. Что могут рассказать географические карты о грядущих конфлликтах и битве против неизбежного, КоЛибри, Азбука-Аттикус, Москва, 2016, сс. 337-366.

${ }^{10}$ In particular, it entails the Asia-Pacific region, which accounts for up to $30 \%$ of the world economy and has a population of 2.2 billion people. Both the United States and China are promoting their trade and economic projects here. Among the most known are the "TransPacific Partnership" (TPP) and the "Regional Comprehensive Economic Partnership " (RCEP). Counter-expansion in the region creates the threat of military clashes, for example, in the waters of the East China Sea. See: Shantanu Roy-Chaudhury, "The Senkaku Islands Dispute", International Policy Digest, Internet: https://www. The Senkaku Islands Dispute (intpolicydigest.org), 20/02/2021.
} 
rival $^{11}$, neither the United States nor China are ready for a military settlement of disputes. ${ }^{12}$ In order to strengthen their positions in a particular macro-region through the transformation of the existing geopolitical fields, the global competitors use different approaches.

The content of these approaches is clearly revealed in the vast territories of the former Soviet Union (hereinafter referred to as the USSR). For the acquisition of the post-Soviet Eurasian heritage, both the United States and China apply quite opposite stratagems, which are nevertheless based on the recognition of two fundamental issues by both sides. First, the space of the former Soviet republics, together with Russia, is a corner stone for determining the outcome of the emerging US-China center-power rivalry, and possibly the subsequent global geopolitical conflict. ${ }^{13}$ Secondly, these territories are under the influence of complex internal integration, reintegration and disintegration processes associated with Russia's attempts to keep the Eurasian states within the endemic field of the former USSR. But since these efforts have not yet resulted in any unambiguous effect, the entire post-Soviet territory is assumed as a conglomerate of local frontier, cross and meta-fields, subject to the amalgamation by one of the two emerging global total geopolitical fields. Keeping this in mind, let us discover the Western (US-oriented) and Chinese systemic strategies for the integration of post-Soviet Eurasia.

\footnotetext{
${ }^{11}$ The US President J. Biden (Joseph Robinette Biden, Jr.), speaking at the Munich Security Conference on February 19, 2021, said that "... the confrontation with China will be tough and uncompromising". See: Remarks by President Biden at the 2021 Virtual Munich Security Conference, Washington, 2021, Internet: https://www. Remarks by President Biden at the 2021 Virtual Munich Security Conference / The White House/Briefing Room/Speeches and Remarks, 20/02/2021.

12 Kevin Rudd, "Short of War. How to Keep U.S.-Chinese Confrontation From Ending Calamity", Foreign Affairs, vol. 100, no. 2, March/April 2021, p.62.

${ }^{13}$ It takes into account, first of all, such unique factors of the Eurasian post-Soviet space as geographical location, natural resources, industrial capabilities, scientific and technical potential, the size and quality of the population, military readiness, including the presence of nuclear weapons in Russia, etc.
} 


\section{The American-style of space acquisition: a combination of political technologies and an institutional strategy}

This goal-setting orientation of foreign policy is laid down in the basic documents of the United States and its alliances - the National Security Strategy (2017) $)^{14}$ and the Strategic Concept of the North Atlantic Treaty Organization (hereinafter referred to as NATO) (2010). ${ }^{15}$ In these and later acts $^{16}$, the US proclaims its main goal in Eurasia as the deterrence of China's dominance in its traditional confrontational style, and the most important means of achieving it is to maximize its presence in this most important geopolitical region. ${ }^{17}$ Some representatives of the political and academic community support the position of the United States authorities, suggesting using the tools of smart power to promote American leadership in the region (Stephen Gallup Brooks, William Curti Wohlforth) ${ }^{18}$ and involving the countries located there in more competitive and attractive institutional systems than those of potential rivals (Robert Dean Blackwill, Jennifer Michelle Harris). ${ }^{19}$ It is worth noting that such a combination of means and methods of securing the territorial space of interest has long been implemented by the United

14 "National Security Strategy of the United States of America (2017)", December 2017, National Security Strategy Archive, Washington, 2017, Internet: https://www. National Security Strategy 2017 - National Security Strategy Archive, pdf (nssarchive.us), 22/02/2021, pp. 1-55.

15 "Active Engagement, Modern Defense (2010)", Strategic Concept for the Defense and Security of the Members of the North Atlantic Treaty Organization, Adopted by Heads of States and Governments at the NATO Summit in Lisbon 19-20 November 2010, Brussels, 2010, Internet: https://www. 20120214_strategic-concept-2010-eng.pdf (nato.int), 22/02/2021, pp. 4-35.

16 "NATO 2030: United for a New Era (2020)", Analysis and Recommendations of the Reflection Group Appointed by the NATO Secretary General 25 November 2020, Brussels, 2020, Internet: https://www. 201201-Reflection-Group-Final-Report-Uni.pdf (nato.int), 22/02/ 2021, 1-67 p.

${ }^{17}$ Ibid., pp. 27-28.

${ }^{18}$ See, for example: Stephen G. Brooks, William C. Wohlforth, "The Once and Future Superpower: Why China Won't Overtake the United States", Foreign Affairs, Issue May/June, 2016, Internet: https://www.foreign affairs.com/articles/united-states/2016-04-13/onceand-future-superpower, 22/02/2021, pp. 91-104.

${ }^{19}$ See, for example: Robert D. Blackwill, Jennifer M. Harris, War by Other Means: Geoeconomics and Statecraft, The Belknap Press of Harvard University Press, Cambridge, 2017. 
States and the Western World as a whole. Within this framework, all actions are strategically clear. They are carried out in accordance with a set of specific rules, and obey a certain logic of behavior.

In the beginning, the political field is cleaned up and the political environment loyal to the United States is arranged, which is achieved by preparing for or directly/indirectly supporting the so-called "color" revolutions. Experts have long focused on the technological nature of this phenomenon, assuming "a new type of political technology aiming at the change of political power". ${ }^{20}$ The definition given by the Russian political scientist S.A. Markov (Сергей Александрович Марков), in our opinion, most fully conveys the nature of the "color" revolutions, since it reflects the high-tech character of this globalization era product and reveals its content as "a set of processes simulating a socio-political revolution". ${ }^{21}$ The analysis of "color" technologies applied in the post-Soviet space shows their rather high effectiveness. During 11 "color" coups in Georgia (2004), Ukraine (2005; 2014), Kyrgyzstan (2005; 2010), Belarus (2006; 2020), Moldova (2009; 2016), Armenia (2015; 2018), political regimes that did not fit into the American "scenario" of world order were crushed or significantly undermined. Their place was taken by proWestern political opponents.

After the "bulldozing" stage (the name of one of the "color" coups), the consolidation of the territory of interest is carried out by organizational measures. These measures clearly contain elements of an institutional strategy. They include (1) the institutionalization itself in the form of offering entrant states legal norms, principles and eligibility criteria for participation in new institutions; (2) the process of institutional mobilization of new recruits, and, finally, (3) the management of the institutions' development in accordance with objectives and mechanisms of the strategy. ${ }^{22}$ Since the 90s of the last century, the United States and the European Union (hereinafter referred to as the EU) have gradually implemented the institutionalization and institutional mobilization of most of the post-Soviet republics within the framework of their unions and projects, thereby finally consolidating the pro-Western foreign

\footnotetext{
${ }^{20}$ Сергей А. Марков, "Цветная революция- это новый тип политических технологий по смене политической власти", Комсомольская правда, 15 ноября 2005, с. 6.

${ }^{21}$ Ibid., c. 6.

${ }^{22}$ See: Igor H. Ansoff, Strategic Management, Palgrave Macmillan, New York, 2007, 251 p.
} 
policy and foreign economic orientation of these countries. Thus, six former Soviet republics, namely, Armenia, Azerbaijan, Belarus, Georgia, Moldova and Ukraine, joined the EU integration initiative "Eastern Partnership", and three of them - Georgia, Moldova and Ukraine signed association agreements and approved the creation of a free trade zone with the EU. ${ }^{23}$ Many more postSoviet states appeared to get integrated into Western military and political institutions. NATO's subsidiary structure - the Euro-Atlantic Partnership Council - has been expanded to include 11 former Soviet republics: Armenia, Azerbaijan, Belarus, Georgia, Kazakhstan, Kyrgyzstan, Moldova, Tajikistan, Turkmenistan, Ukraine and Uzbekistan. ${ }^{24}$ Currently, the United States and the EU have initiated a phase of internal consolidation of established institutions by means of the mechanism of "multi-speed (Europe) integration" 25 as well.

It can be concluded that the systemic strategy of the Western World to involve post-Soviet Eurasia in the field of its dependence is characterized by pragmatism and efficiency, and has chances for further development in spatial and temporal dimensions. At the same time, we define pragmatism as the moderate cost of the technologies used ("color" coups); efficiency as the ability to solve several strategic tasks at once (military and political dominance, expansion of the influence sphere, deterrence of opponents); and perspective as the prediction of the future (taking into account the plans of the new US Administration in the Euro-Atlantic and Eurasian zones). ${ }^{26}$

\footnotetext{
${ }^{23}$ Seе: Анна Ф. Дырина, "Восточное партнерство: От идеи к реализации", Актуальные проблемы Европы, 2019, №3, сс. 217-234.

${ }^{24}$ Seе: Роберт Ф. Симмонс мл., "Совету евроатлантического партнерства десять лет: личные размышления", Вестник НАTO, лето 2007, Internet: https://www. nato.int/docu/ review/2007/issue2/russian/art5.html, 24/02/2021.

${ }^{25}$ The most promising in terms of the integration of Ukraine, Georgia and Moldova are being supported by the EU special programmes of "privileged partnership". See: Stanislav Secrieru, Sinikukka Saari, The Eastern Partnership. Looking back, thinking ahead, European Union Institute of Security Studies (EUISS), Publications Office of the EU, Luxembourg, 2019, pp. 28-71. Besides, the "strengthened partnership" regime is envisaged for the same states, with the prospect of membership in NATO. See: "NATO 2030: United for a New Era ", op. cit., p. 59.

${ }^{26}$ Jessica M. Mathews, "Present at the Re-creation? U.S. Foreign Policy Must Be Remade, Not Restored", Foreign Affairs, vol. 100, no. 2, March/April 2021, p. 15.
} 


\section{The Chinese Way: integration focusing on economic expansion}

China's advance deep into Eurasia mainland dates back to the 2000s, when national and private corporations of this country began intensive export of capital abroad. The policy of developing space by economic means is the crucial point of all Chinese global projects of recent times, which, by the way, the US has not reached yet. Consistently put forward by the ruling Communist Party of China and such complementary initiatives as "Going out" (encouraging businesses to invest in the mining sectors of economy abroad, 2000), "Great Western Development Strategy-2030" (accelerated development of China's Western provinces through the intensification of trade and economic relations with Central Asia, 2011), "Building the Community of Common Destiny" (state stimulation of economic relations expansion with foreign countries, 2012), "One Belt, One Road" (creation of a network of international transport communication routs, 2013), "Dual Circulation Strategy" (harmonization of expanding export operations and commodity-money circulation within the domestic consumer market, 2020) were more or less grounded on economic expansion outside the country borders. ${ }^{27}$

The principle instruments for promoting Chinese outbound interests were, and still are, investments which have a number of significant features. They (a) are massive in character, (b) implemented on extremely favorable terms for recipients; (c) carried out under the sectoral pattern in the interests of the investor. For example, the volume of capital exported from China in 2017 amounted to approximately US\$135 billion, of which at least US\$100-105 billion was accounted for by the participants of the "One Belt, One Road" Initiative, including the countries of Central Asia and Transcaucasia, Russia and Belarus. ${ }^{28}$ At the same time, the United States' investments in the Eurasian

\footnotetext{
${ }^{27}$ See, for example: David Orsmond, "China's Economic Choices", Analyses, Lowy Institute, Sidney, 2019, Internet: https://www. China's Economic Choices/Lowy Institute, 27/02/2021; Frank Tang, "What is China's dual circulation economic strategy and why is it important?", South China Morning Post, 19 November 2020, Internet: https://www. What is China's dual circulation economic strategy and why is it important? / South China Morning Post (scmp.com), 27/02/2021.

28 "Belt and Road Initiative gives boost to Chinese outbound investments (2019)", American Enterprise Institute, Washington, 25 March 2019, Internet: https://www. Belt and Road Initiative gives boost to Chinese outbound investments/ Business Standard News (businessstandard.com), 28/02/2021.
} 
region in 2017 amounted to US\$ 36.7 billion or 1\% of all its foreign investments. ${ }^{29} \mathrm{~A}$ significant part of Chinese capital flows to recipients not in the form of foreign direct investment, such as Americans or Europeans do, but in the form of soft loans, as well as interest-free loans and grants, often conducted through offshore zones. ${ }^{30}$ Unlike investment projects of other countries, which are usually "fan-shaped", China's investments in the Eurasian countries keep a point-by-point strategy for the primary (mining and fuel facilities) and tertiary (transport and logistics) sectors of the economy. ${ }^{31}$ Often, investments are secured by assets, which make them as safe as possible for the Chinese party, and shifts all the risks to the receiving side. ${ }^{32}$ The combination of all these features of the investment policy provides China with significant advantages over its closest competitors in the development of the areas of interest.

International lending has become a very effective tool for Chinese expansion in post-Soviet Eurasia. Lending is provided, as a rule, on preferential terms, which is expressed in the provision of borrowed funds with an interest rate below the market, in the rejection of "tough" debt repayment schemes, the permissibility of securing loans with commodity products, as well as in the general non-transparency of credit operations. ${ }^{33}$ Taking into account such preferences, the republics of the former USSR are willing to take China's loans in an increasing progression. For example, the average debt of the 50 main borrowers of direct loans from China (including such Central Asian countries as Kyrgyzstan, Tajikistan, Turkmenistan, and Uzbekistan) increased from less than $1 \%$ of GDP in 2005 to more than $15 \%$ of the debtor countries' GDP in 2017. In a number of these countries, the debt burden to China is on average

${ }^{29}$ Софья В. Андросова, Александра Е. Румянцева, "Иностранные инвестиции в страны Евразийского экономического союза", Молодой ученый, 2017, №51, с. 143.

${ }^{30}$ Сергей Б. Маргулис, Сложный инвестор. Во что вкладывает деньги Китайская Народная Республика в странах бывщего СССР, Научно-исследовательский центр проблем интеграции стран-участниц Евразийского экономического союза "Союзный нарратив 2050", Москва, с. 27.

${ }^{31}$ Ibid., c. 5.

32 Ibid., c. 27.

${ }^{33}$ See: Sebastian Horn, Carmen Reinhart, Christoph Trebesch, "China's Overseas Lending", Kiel Working Paper, 2019, no. 2132, June 2019, pp. 20-25. 
more than $40 \%$ of the total external debt, for example, in Kyrgyzstan and Tajikistan. ${ }^{34}$ The growing debt dependence does not prevent the national authorities from further borrowing, since China is quite liberal in offering debt security instruments. Loans are usually secured against assets, including deposits, industrial facilities, and strategic infrastructure. The latter circumstance gives grounds for experts and observers to talk about a "debt trap" for the borrowing countries and even about the gradual "invoking of states as eminent domain" in favor of China. ${ }^{35}$

Foreign trade policy has been a significant help in strengthening China's position in Eurasia. With an exceptional leadership in the volume of industrial production of US\$ 9.4 trillion (the EU $-\$ 5.2$ trillion, the US $-\$ 3.7$ trillion) $^{36}$, China "throws out" huge surpluses of commodity products abroad, remaining at an unattainable level also keeping the ratio of exports in global trade with an indicator of US\$2.48 trillion against US\$ 1.66 trillion in the United States. ${ }^{37}$ At the regional level, China's trade proportion looks even more significant. For example, in the post-Soviet states of Central Asia, the main weight of their imports falls on China, namely, Kazakhstan - 48.8\% (US\$ 12.7 billion), Kyrgyzstan - 24.1\% (US\$ 6.3 billion), Uzbekistan - 19.3\% (US\$ 5.0 billion), Tajikistan $-6.1 \%$ (US\$ 1.6 billion), despite the fact that the United States is not even in the top 10 of trading partners of these countries. ${ }^{38}$ China's imports and resources outnumber those of the United States in the European states of the former Soviet Union. ${ }^{39}$ In recent years, an important feature of China's foreign

\footnotetext{
${ }^{34}$ See: John Hurley, Scott Morris, Gailyn Portelance, Examining the Debt Implications of the Belt and Road Initiative from a Policy Perspective, Centre for Global Development, Washington, D.C., 2018, p. 20.

${ }^{35}$ Елена Г. Пономарева, Дмитрий Д. Крыканов, "Балканское дыхание Пекина. Стратегия и тактика китайского присутствия в странах Западных Балкан", Полития/Politeia, 2020, № 1, с. 127.

36 "Global Economic Prospects (2020)", Flagship report, June 2020, World Bank Group, Washington, D.C., 2020, p. 8.

37 "Global Economic Prospects (2020)", op. cit., p. 10.

38 Яков А. Суходолов, "Торгово-экономическое сотрудничество Китая со странами Центральной Азии", Известия Байкальского государственного университета, 2020, T.30, № 1, с. 51.

${ }^{39}$ According to the relevant data for 2019, imports from China to Belarus amounted to US\$ 3.84 billion against US\$ 515 million from the United States, to Ukraine - US\$ 8.3 billion against US\$ 1.5 billion, to Azerbaijan - US\$ 13.1 billion against US\$ 6.8 billion, to Armenia - US\$ 664
} 
trade policy has been that the state and private companies in China are gradually changing the structure of exports towards high-tech products with high added value (e.g., the strategic plan "Made in China - 2025")..$^{40}$ China is vigorously reserving additional market space for these products. And this is happening very fast. In the same Central Asian republics, imports from China have increased by 76 times over the past 25 years, from 0.17 to 13.0 billion US dollars, while the export rate of neighboring Russia does not exceed 4.7 times - from 4.14 to 19.5 billion US dollars. ${ }^{41}$ It is quite obvious that, in the medium-term perspective, China will solve both applied problems related to excess production capacity and commodity overproduction, and promote strategic goals aimed at creating prerequisites for economic integration in Eurasia through massive export expansion.

Keeping in mind the traits of China's stratagem of the Eurasian space development, we cannot but recognize such qualities as its naturalness, thoroughness, and geopolitical depth. The emphasis on "softer" (economic, financial, trade), in other words, peaceful and coercive means of influence, literally pushes potential partners towards Beijing, making the Chinese factor work for itself. China's approach is more fundamental, as it is based on a chain of conceptually structured and mutually stimulating global projects and initiatives. And the most important goal of this stratagem - the creation of a single Eurasian economic space in which China will play a key role - is achieved through the structure-building factors of the development of geopolitical space-oriented reference points (commodity markets) and geopolitical lines connecting them (international transport corridors).

million against US\$ 179 million from the United States. See: "Об итогах внешней торговли Евразийского экономического союза (январь-декабрь 2019 года) (2020)", Аналитический обзор 25 февраля 2020 г., Евразийская Экономическая Комиссия, Москва, с. 8.

${ }^{40}$ See: Elaine Chan, "Made in China 2025": is Beijing's plan for in-tech dominance as big a threat as the West thinks it is?", South China Morning Post, 10 September 2018, Internet: https://www. 'Made in China 2025': Is Beijing's plan for hi-tech dominance as big a threat as the West thinks it is? / South China Morning Post (scmp.com), 03/03/2021.

${ }^{41}$ Александр П. Поливач, "Торговля стран Центральной Азии с Россией и Китаем", Россия и новые государства Евразии, 2019, № 4, с. 137. 


\section{Russian geopolitical perspectives in Eurasia: maintaining pole subjectivity through internal modernization}

Russia is a relatively weak actor in the center-power rivalry between the United States and China, primarily from the economic point of view. Its ratio in the global GDP is about $2 \%$, and the economic outlook is still largely dependent on the global energy and raw materials environment. Unlike the USSR, modern Russia is not able to pursue global geopolitics. ${ }^{42}$ Russian geopolitics is mainly local in nature and is focused predominantly on the postSoviet space as a zone of its vital interests. The main strategic goal of Russia in the near and medium term is to keep the members of the Commonwealth of Independent States (hereinafter referred to as the CIS) within their geopolitical total field and reintegrate some of them into the endemic field, as it used to be during the USSR era. ${ }^{43}$ Achieving this aim in the context of the emerging new relative bipolarity of the world is extremely difficult but still possible depending on the composition of favorable internal and external factors.

The external environment will, of course, be determined, by the degree of insolubility of contradictions and the severity of the confrontation between the United States and China at the global level. Therefore, it will be relevant for Russia to develop a new Eurasian geo-strategy that takes current realities into account, assuming flexible, diversified approaches in relations with the two powers of global domination, and utilizing differences between them in the macro-region in its own national interests. ${ }^{44}$

At the same time, the endogenous potential of Russia is crucial in determining whether Russia will be able to maintain the integration initiative in the post-Soviet space or face the threat of interception of this initiative by other powers. Much will depend on the ability of Russian society and the state

\footnotetext{
${ }^{42}$ For comparison: the ratio of the USSR economy in the global GDP in 1980 was $11.71 \%$ (the United States - 21.36\%).

43 "Концепция внешней политики Российской Федерации (2016) ", Утверждена Указом Президента Российской Федерации от 30 ноября 2016 г. № 640, Москва, 2016, Гл. IV, Ст. 49, Internet: https://www. kremlin.ru/acts/bank/41451, 05/03/2021, cc. 22-23.

${ }^{44}$ Николай А. Баранов, "Соперничество США, Китая и России как глобальный геополитический конфликт", Персональный сайт Николая Баранова, май 2019, Internet: https://www. Тема 15. Соперничество США, Китая и России как глобальный геополитический конфликт (nicbar.ru), 06/03/2021.
} 
to move forward towards creating an innovative economy and an effective political and institutional system. This condition is directly related to the objective possibility of Russia offering an attractive idea (model) of joint development to neighboring countries. ${ }^{45}$ China's experience indicates that the preservation of the pole subjectivity of the center of influence is inconceivable without retaining the peripheral space in the zone of economic and trade activities of the center. Russia still maintains the primacy in export-import operations with the majority of CIS members, but loses its positions in terms of investment and international lending to China and the EU. ${ }^{46}$ It is in Russia's interests to overcome this imbalance and reach new competitive economic indicators. The success of the implementation of integration projects is determined by the effectiveness of the institutional framework of the entire integration policy. The regional organizations headed by Russia, the Eurasian Economic Union (hereinafter referred to as the EAEU) and the Collective Security Treaty Organization (hereinafter referred to as the CSTO), are limited in their capabilities mainly due to the lack of integration with the world's leading economic projects, for example, the Chinese initiative "One Belt, One Road", or the absence of any integration into Western structures, the EU or NATO. In the current situation, the urgent steps could include a set of measures aiming, first of all, to deform and de-bureaucratize the institutional environment of the pro-Russian Eurasian integration processes. Today, "soft power" is becoming increasingly important as a means of achieving foreign policy goals. The favorable international image and high quality of life of the population of a state that claims to become an integration center can not only raise its prestige in eyes of other parties, especially its neighbors, but also disable foreign hybrid attacks and "color" projects there. In this regard, according to the Russian political scientist N.A. Baranov (Николай Алексеевич Баранов), Russia will have to "change its reality". ${ }^{47}$

Summing up, we can affirm that Russia has all the chances to remain one of the leading factors in the Eurasian arena as a trans-regional power in Europe

\footnotetext{
45 Seе: Наум М. Сирота, Геннадий А. Мохоров, "Соперничество США, Китая и России как глобальный геополитический конфликт", Клио, 2017, № 11(131), с. 188.

${ }^{46}$ Андроник А. Мигранян, "Россия и государства СНГ: проблемы и перспективы экономического развития", Постсоветский материк, 2017, №4(16), сс. 91-92.

${ }^{47}$ Николай А. Баранов, "Соперничество США, Китая и России как глобальный геополитический конфликт", ор. cit.
} 
and Asia. The legacy inherited from the USSR creates a good basis for this, but it will require its own considerable modernization efforts. Otherwise, as follows from the above, all other scenarios for Russian integration initiatives, and for Russia itself, will be negative.

\section{Conclusion}

The foregoing allows us to make several preliminary generalizations. The geopolitical "Global Island", which is the Eurasian continent and the post-Soviet space as its core component, is currently undergoing an internal structural adjustment under the influence of the development of a new relative bipolarity with China as the second pole and the globalization core alternative to the United States. The vector of these changes has formed steadily. It clearly indicates the transition of the former Soviet territorial heritage, previously considered the endemic field of the USSR, and later becoming the total field of the Russian Federation, to the category of a frontier geopolitical field comprising elements of a cross field (the European part of the post-Soviet space) and a meta-field (the Central Asian countries). The subjects of space exploration - the Western World in the vanguard with the United States and China - include the territories of the former USSR in their zone of vital interests, and regard them in the perspective of the upcoming global confrontation (or even open conflict) as a universal and multifunctional source that can strengthen the position of one party and weaken the status of the opposing one. The interests of the United States are not yet limited to the "material" development of the territory, but rather have an applied, tactical nature targeting to consolidate the European post-Soviet republics into the system of Western military and political alliances, thereby preventing China's advance deeper into Europe. The rest of the Asian part of the former Soviet Union is affected by the efforts of the United States to create a belt of tension and conflict around the perimeter of China's borders, which helps to deter the latter. The Western World will not definitely abandon its attempts to destabilize Russia in order to reduce the country's attractiveness for an alliance with China. China's claims to the Eurasian macro-region are strategic in nature, as they have deeper geo-economic and geopolitical dimensions. China plans to integrate all post-Soviet states, including Russia, into a single Eurasian economic space, where it could play a system-forming role. Under this mega 
project, China will seek to build up political ground, since most of the political opponents of the United States, such as Russia, Iran, and Pakistan, will be united in a common space with it. Though the "hard" scenario in respect to the United States does not seem a part of China's immediate interests, there is an objective basis for confrontational engagement with the leader of the Western World in China's policy. Whether post-Soviet Eurasia will share the fate of other regions of the world, where the US-China confrontation is taking a sharp form, depends, among other things, on Russia, its integration potential and geopolitical self-determination in the globalizing world.

\section{References}

"2020 Annual Report to Congress of the U.S.- China Economic and Security Review Commission (2020)", One Hundred Sixteenth Congress, Second Session, December 2020, U.S.-China Economic and Security Review Commission, Washington D.C, 2020, Internet, https://www.uscc.gov/ 2020/Annual Report to Congress U.S.- China Economic and Security Review Commission/ text pdf, 18/02/2021, pp. 1-533.

"Active Engagement, Modern Defense (2010)", Strategic Concept for the Defense and Security of the Members of the North Atlantic Treaty Organization, Adopted by Heads of States and Governments at the NATO Summit in Lisbon 19-20 November 2010, Brussels, 2010, Internet: https://www. 20120214_strategic-concept-2010-eng.pdf (nato.int), 22/02/2021, pp. 1-35.

Александр Поливач, "Торговля стран Центральной Азии с Россией и Китаем", Россия и новые государства Евразии, 2019, №4, сс. 136-147. Андроник Мигранян, "Россия и государства СНГ: проблемы и перспективы экономического развития", Постсоветский материк, 2017, № 4(16), cc. 88-104.

Анна Дырина, "Восточное партнерство: От идеи к реализации", Актуальные проблемы Европы, 2019, №3, сс. 217-234.

Arvind Subramanian, Eclipse: Living in the Shadow of China's Economic Dominance, Peterson Institute for International Economics, Washington, 2011, 216 p. 
"Belt and Road Initiative gives boost to Chinese outbound investments (2019)", American Enterprise Institute, Washington, 25 March 2019, Internet: https://www. Belt and Road Initiative gives boost to Chinese outbound investments/ Business Standard News (business-standard.com), 28/02/2021.

David Orsmond, "China's Economic Choices", Analyses, Lowy Institute, Sidney, 2019, Internet: https://www. China's Economic Choices/Lowy Institute, 27/02/2021.

Elanie Chan, "Made in China 2025: Is Beijing's plan for in-tech dominance as big a threat as the West thinks it is?", South China Morning Post, 10 September 2018, Internet: https://www. 'Made in China 2025': Is Beijing's plan for hi-tech dominance as big a threat as the West thinks it is? / South China Morning Post (scmp.com), 03/03/2021.

Елена Пономарева, Дмитрий Крыканов, "Балканское дыхание Пекина. Стратегия и тактика китайского присутствия в странах Западных Балкан", Полития/Politeia, 2020, № 1, cc. 117-138.

Frank Tang, "What is China's dual circulation economic strategy and why is it important?", South China Morning Post, 19 November 2020, Internet: https://www. What is China's dual circulation economic strategy and why is it important? / South China Morning Post (scmp.com), 27/02/2021.

Global Economic Prospects (2020), Flagship report, June 2020, World Bank Group, Washington, D.C., 2020, pp. 1-216.

Henry Kissinger, World Order, Penguin, New York, 2014, 432 p.

Igor H. Ansoff, Strategic Management, Palgrave Macmillan, New York, 2007, $251 \mathrm{p}$.

Jessica M. Mathews, "Present at the Re-creation? U.S. Foreign Policy Must Be Remade, Not Restored", Foreign Affairs, vol. 100, no. 2, March/April 2021, pp. 10-16.

John Hurley, Scott Morris, Gailyn Portelance, Examining the Debt Implications of the Belt and Road Initiative from a Policy Perspective, Washington, D.C., Centre for Global Development, 2018, 38 p.

Kevin Rudd, "Short of War. How to Keep U.S.-Chinese Confrontation From Ending Calamity", Foreign Affairs, vol. 100, no. 2, March/April 2021, pp. 58-73. 
Константин Плешаков, "Геополитика в свете глобальных перемен", Международная жизнь, 1994, №10, сс. 30-39.

"Концепция внешней политики Российской Федерации (2016)", Утверждена Указом Президента Российской Федерации от 30 ноября 2016 г. № 640, Москва, 2016, Internet: https://www. kremlin.ru/ acts/bank/41451, 05/03/2021, cc. 1-38.

"National Security Strategy of the United States of America (2017)", December 2017, National Security Strategy Archive, Washington, 2017, Internet: https://www. National Security Strategy 2017 - National Security Strategy Archive, pdf (nssarchive.us), 22/02/2021, pp. 1-55.

"NATO 2030: United for a New Era (2020)", Analysis and Recommendations of the Reflection Group Appointed by the NATO Secretary General 25 November 2020, Brussels, 2020, Internet: https://www. 201201Reflection-Group-Final-Report-Uni.pdf (nato.int), 22/02/2021, pp. 1-67.

Наум Сирота, Геополитика, Питер, Санкт-Петербург, 2006, 176 с.

Наум Сирота, Геннадий Мохоров, "Соперничество США, Китая и России как глобальный геополитический конфликт", Клио, 2017, № 11(131), сс. 186-190.

Николай Баранов, "Соперничество США, Китая и России как глобальный геополитический конфликт", Персональньй сайт Николая Баранова, май 2019, Internet: https://www. Тема 15. Соперничество США, Китая и России как глобальный геополитический конфликт (nicbar.ru), 06/03/2021.

"Об итогах внешней торговли Евразийского экономического союза (январь-декабрь 2019 года) (2020)", Аналитический обзор 25 февраля 2020 г., Евразийская Экономическая Комиссия, Москва, сс.1-15.

Remarks by President Biden at the 2021 Virtual Munich Security Conference, The White House, Washington, 2021, Internet: https://www. Remarks by President Biden at the 2021 Virtual Munich Security Conference /The White House/ Briefing Room/Speeches and Remarks, 20/02/2021.

Robert D. Blackwill, Jennifer M. Harris, War by Other Means: Geoeconomics and Statecraft, The Belknap Press of Harvard University Press, Cambridge, 2017, 366 p.

Роберт Каплан, Месть географии. 4 то могут рассказать географические карты о грядущих конфликтах и битве против 
неизбежного, Пер. с англ. М. Котова, КоЛибри, Азбука-Аттикус, Москва, 2016, 384 с.

Роберт Ф. Симмонс мл., "Совету евроатлантического партнерства десять лет: личные размышления", Вестник HАTO, лето 2007, Internet: https:// www.nato.int/docu/review/2007/issue2/russian/art5.html, 24/02/2021.

Sebastian Horn, Carmen Reinhart, Christoph Trebesch, "China's Overseas Lending", Kiel Working Paper, 2019, no. 2132, June 2019, 77 p.

Сергей Маргулис, Сложный инвестор. Во что вкладывает деньги Китайская Народная Республика в странах бывшего СССР, Научноисследовательский центр проблем интеграции стран-участниц Евразийского экономического союза "Союзный нарратив 2050", Москва, 29 с.

Сергей Марков, "Цветная революция - это новый тип политических технологий по смене политической власти", Комсомольская правда, 15 ноября 2005, с. 6.

Shantanu Roy-Chaudhury, "The Senkaku Islands Dispute", International Policy Digest, Internet: https://www. The Senkaku Islands Dispute (intpolicydigest.org), 20/02/2021.

Софья Андросова, Александра Румянцева, "Иностранные инвестиции в страны Евразийского экономического союза", Молодой ученый, 2017, № 51, cc. 141-144.

Stanislav Secrieru, Saari Sinikukka, The Eastern Partnership. Looking back, thinking ahead, European Union Institute of Security Studies (EUISS), Publications Office of the EU, Luxembourg, 2019, 116 p.

Stephen G. Brooks, William C. Wohlforth, "The Once and Future Superpower: Why China Won't Overtake the United States", Foreign Affairs, Issue May/June, 2016, Internet: https://www.foreign affairs.com/articles/unitedstates/2016-04-13/once-and-future-superpower, 22/02/2021, pp. 91-104. Яков Суходолов, "Торгово-экономическое сотрудничество Китая со странами Центральной Азии", Известия Байкальского государственного университета, 2020, Т.30, № 1, сc. 50-58. 